\section{MUJER, ¿TÚ QUIÉN ERES? SÉ TÚ MISMA. LA DESIGUALDAD NO ESTÁ EN LOS GENES}

WOMAN, WHO ARE YOU? BE YOURSELF. INEQUALITY IS NOT IN THE GENES

Casimiro Bodelón Sánchez

\section{Resumen:}

Abstract:

En este breve ensayo se plantea la cuestión In this brief essay a question is exposed "¿qué es ser mujer?" y todo lo que eso implica from an anthropologic perspective: "what is desde una perspectiva antropológica, con being a woman?" and everything which it el fin de conocer todos los aspectos que involves, with the purpose of knowing every conforman la identidad femenina y superar aspect which build the female identity and los prejuicios y estereotipos que la sociedad overcoming the prejudices and stereotypes impone. which are imposed by the society.

\section{Palabras claves}

Mujer, yo, humano.

\section{KEY WORD:}

Woman, I, human.
"Los hombres, a veces, son dueños de sus destinos:

la culpa, querido Bruto, no está en nuestra estrella,

sino en nosotros mismos, si nos resignamos a la inferioridad..."

(Julio César, I, II)

“... las desigualdades de riqueza, poder y status no son naturales,

sino obstáculos impuestos socialmente a la construcción de una sociedad

en la que el potencial creativo de todos sus ciudadanos

sea empleado en beneficio de todos"

(Lewontin, Rose y Kamin, 1987: 21)

Mientras tú no seas plenamente TÚ y yo no sea plenamente YO, es inútil y vacío hablar del NOSOTROS. Nuestros encuentros, nuestras relaciones, serán superficiales, ficticias, crudas-sangrantes, objetivantes, de uso-abuso mutuo y, por lo mismo, incubadoras de ese mal llamado depresión, expresión de la tristeza (consciente o inconsciente) de no haber conseguido lo fundamental: ser yo mismo, en compañía de un tú mismo, que decimos NOSOTROS.

Nuestro filósofo Ortega y Gasset acuñó esa feliz expresión: “Yo soy yo y mi circunstancia". Pues bien, la mayoría de los humanos llegamos a conocer (mal que bien) las circunstancias múltiples y plurales que nos van modelando a lo largo de la vida, pero en raras ocasiones nos planteamos conocer "quién soy yo". Las circunstancias son siempre "lugares de encuentro o des-encuentro" de un YO con un TÚ o de un YO consigo mismo, pero cuando el YO o el TÚ no se conocen, tales encuentros, en el mejor de los casos, resultan vacíos, porque lo importante de todo encuentro para que sea tal son las personas conscientes de sí, no tanto de lo que les rodea (circunstancia = circum stare). Yo que os hablo (varón) y "tú" que me escuchas (mujer), por el simple hecho de haber nacido "PERSONA", ya tengo, tienes, tenéis SENTIDO, VALOR, al margen del resto de circunstancias (¡sean las que sean!). Pero también afirmo, siguiendo a Ortega, que el primer sentido-valor de la existencia humana y personal se va a enriquecer o empobrecer, según las relaciones que mantengamos con lo/los que nos circunden (nuestras circunstancias)

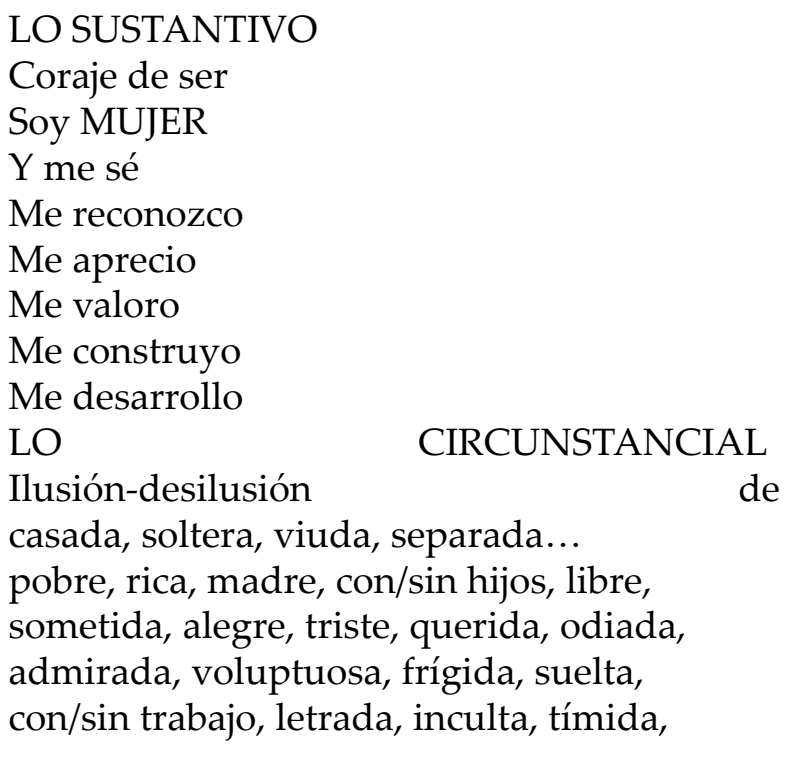


descarada, creyente, incrédula, de derechas o de izquierdas...

Y vivo y decido como MUJER

Todo lo sustantivo es esencial y en ello debemos emplear nuestras mejores energías lo que es circunstancial, adjetivo de nuestras vidas, es importante, pero ni mucho menos lo más importante, por más que haya quien centre en ello toda su vida. Cada uno de nosotros, sin duda, va a tener un sinfín de circunstancias que matizarán nuestro vivir. Pero lo que está claro para mí es que una vida poco sustantiva, por lo mismo poco humana, va a intentar "camuflarse" con múltiples adjetivos "circunstanciales", y habrá que concluir con el dicho: "aunque la mona se vista de seda...". Quien prima en exceso sus circunstancias adjetivantes, acaba rebajando, si no anulando, su sustantividad.

\section{¿Qué es ser mujer?}

Volvamos a la gran pregunta: ¿qué es ser mujer? "Sumisión y mansedumbre" son características que trasmiten y sostienen el Estado, la moral, las religiones, la ciencia y hasta la mala psicología. Todos ellos han sostenido y algunos aún siguen sosteniendo que ese ser llamado mujer tiene como destino propio conseguir marido, tener hijos y criarlos; dicho de otro modo, ser una paridera (Mizrahi , 1992: 13), o lo que es lo mismo, mujer = útero, por lo que dijo santo Tomás: "Mulier est id quod est, propter uterum". Es decir, la mujer sólo consigue una entidad propia, si cumple las leyes (escritas o tácitas) que otros escribieron para ella.

"Las mujeres -escribe Liliana Mizrahi- son tratadas de una manera no muy diferente de como se trata aún hoy a los negros en muchas partes del mundo. En una sociedad patriarcal, las mujeres siempre fueron consideradas ciudadanos de segunda clase" (Mizrahi , 1992: 85). Prejuicios sobre la mujer:

1.- las mujeres tienen un cerebro más pequeño que los hombres

2.- son menos inteligentes

3.- son más emotivas e inestables

4.- en las urgencias, sólo saben desmayarse

5.- son débiles y enfermizas

6.- tienen escasa capacidad de descubrimiento y menos sentido común

7.- no se les puede encomendar el manejo de la economía y fuera de la casa sólo pueden

8.- ser útiles en los trabajos más rutinarios y vulgares

Por su parte, Ney Bensadon, en Los derechos de la mujer, subraya lo siguiente: "Durante mucho tiempo el hecho de ser mujer ha sido motivo de restricción de derechos y libertades pisoteadas (7). Los hombres, (varones) apartan del poder político a las mujeres, bajo pretexto de ideas preconcebidas, de dogmas profesados que tienen la apariencia de una verdad demostrada: éstos son los mitos. El gran poder de los mitos es inmenso y superior a todos los ejércitos del mundo (15). Estos mitos son utilizados por el poder de turno, personal y dictatorial o religioso y social, para no otorgar a la mujer los mismos derechos de que disfruta el varón (26). Todo racismo, toda opresión daña, envilece, empobrece. La misoginia fue el primero y el más antiguo de los racismos" (150).

Liliana Mizrahi afirma con toda contundencia: “La ética de la sumisión a un orden doméstico y burocrático obstaculiza la búsqueda de nuestra verdadera identidad. La vida de las mujeres gregarias se ha convertido en una verdad axiomática: vivir es adecuarse a lo inadecuado, someterse y renunciar" (1990: 40).

Es indudable que más de una ha intentado liberarse de este yugo, pero la mano férrea del dictador dispone de un arma paralizante, la culpabilización. "La culpa se inscribe en nuestro inconsciente como uno de los códigos escritos, el más antiguo y el más primitivo de la humanidad. Se manifiesta a través de prohibiciones, abstenciones y restricciones intangibles e inmotivadas en la mayoría de los casos. Las leyes internas de la culpa están dirigidas a los deseos más primitivos del ser humano. Esto no se hace, esto no se toca, esto no se piensa, esto no se siente, esto no se mira. Se prescribe la prohibición" (Mizrahi, 1990: 44). Los mitos, esas verdades inamovibles, indiscutibles, dogmáticas, paralizan frontalmente cualquier intento de cambio, son el anti-cambio, son valores del pasado, son sagrados, intocables. El cambio es el valor de futuro, de proyecto de posibilidades nuevas, mejores. Quien ancla su vida en los mitos (irracionales-arracionales) se orienta hacia el ayer. Quien apuesta por la vida, la evolución, el proceso progresivo, por el cambio, apuesta por el mañana. Éste nunca está hecho (sí el ayer): por eso el mañana de cada uno de nosotros será nuestra obra, lo que seamos capaces de hacer no lo que otros nos han hecho o quieren que sigamos haciendo. Los del ayer siguen dependiendo de los otros; viven de rodillas y agradecidos a sus ancestros, carecen de autonomía, son heterónomos, sumisos y obedientes; aceptan ser clase "pasiva". Quienes apuestan por el futuro, son evolucionistas; definen su vida como un proyecto no realizado, sino en fase de ejecución; se consideran parte de la naturaleza que nace, crece y decae (muere); están dentro de la matriz humana-circunstancial. Como seres que se saben limitados y mortales, quieren aprender a vivir.

\section{LA MUJER ANCESTRAL Y LA MUJER TRANSGRESORA}

La mujer ancestral que habita dentro de cada una de vosotras "responde a los mandatos históricos que ha recibido, muchos de los cuales tienen el valor de verdades consagradas universalmente" (Mizrahi, 1992: 88). Lo ancestral tiene en cada mujer sus 
características propias, según su historia individual, según los matrices en que se haya gestado o se siga gestando. Lo ancestral viene a ser todo aquello que no acepta las transformaciones del tiempo. Sin embargo, debéis recordar que, por condicionadas que estéis, siempre queda un resquicio para poder decir ¡NO!. Por muy troqueladas y condicionadas que estéis, el argumento de vuestras vidas no está escrito de forma definitiva y nadie debe escribirlo sin vuestro consentimiento. Parodiando a Julio César, “...la culpa, querido Bruto, no está en nuestra estrella, sino en nosotros mismos, si nos resignamos a la inferioridad"

Para poder liberarse, la mujer necesita saber lo que pide su personaje ancestral: sus quejas, sus verdades, sus mandatos, sus miedos, sus deseos y sus esperanzas. Este "troquelado ancestral" que todas habéis (hemos) recibido, no puede ser negado, pero debemos reubicarlo, para dar lugar a la llamada mujer transgresora y libre. Ésta dice a la ancestral: "Yo sin vos no puedo vivir, pero con vos así, tampoco. Te ruego que te desplaces" (Mizrahi, 1992: 89). La mujer que aspira a conquistar su verdadera identidad deberá luchar contra todo lo que en ella aspira al "sometimiento". La mujer ancestral se desarrolla en un molde gestado previamente. Por su parte, la mujer transgresora se ha arrancado la mordaza y denuncia lo que la ancestral no se atreve a decir. La transgresora pone en crisis valores que le impiden vivir; la mujer ancestral suscribe pactos perversos, con el fin de que nada cambie y todo siga como está; vive con miedo, teme, se detiene. La mujer transgresora se atreve y avanza. La ancestral "ya es" lo que otros decidieron que sea, mientras la transgresora "trata de ser" lo que ella desea llegar a ser, porque tiene muy claro que ningún ser humano, y tampoco ella, viene al mundo como un proyecto acabado y cerrado, sino como proyecto abierto y dispuesto a la realización personal. La mujer ancestral tiende al conformismo, a la satisfacción pasiva. Nunca sabe si ella elige o si la eligen, si decide por sí o deja que otros decidan por ella. Por su parte, la mujer transgresora vive en otro nivel de satisfacción: se sabe combatiente y conquistadora del propio destino, constructora de su propio proyecto. Tiene muy claro que en la creación no es un ser de segundo orden, sino PER-SONA, así, en superlativo con PER (como per-cutir, per-forar, per-turbar, per-feccionar, etc.).

La mujer ancestral se siente satisfecha pensando que sus antepasados la miran complacidos, porque cumple a rajatabla sus mandatos y no ha puesto en duda ninguno de sus mitos. Su alegría tiene poco de propia, es la alegría de los otros. Por el contrario la alegría de la transgresora es absolutamente propia, por haber conseguido algo en la lucha, por haber creado algo nuevo, la alegría de haber sido consecuente con su proyecto, a costa de saltarse el proyecto encorsetado que quisieron imponerle. La mujer ancestral -dice Liliana Mizrahi (1990:40)-, ata y desata a diario los hilos del poder y la dominación... adora lo uniforme, imita modelos gregarios y reprimidos, se adecua a lo inadecuado, niega la realidad, altera su percepción, sostiene formas desactualizadas y decadentes que mantienen su dominio, renueva contratos absurdos y legitima instituciones opresivas... todo, con tal de evitar el cambio. Se cumple en ellas lo que afirma Rouseau: "Los esclavos pierden todo con las cadenas, hasta el deseo de escapar de ellas, acaban cobrando cariño a la servidumbre como los compañeros de Ulises al embrutecimiento". Cómo entender esta especie de síndrome de Estocolmo, lo explica con lucidez extraordinaria Anne Wilson Schaef: “Es difícil distanciarse del Sistema del Macho porque en nuestra cultura está en todas partes [...]Se nosha educado política, económica, o filosófica y teológicamente en ella (en esa cultura), y nuestra supervivencia espiritual ha dependido de nuestro conocimiento y mantenimiento de esta serie de normas. [...] En nuestra cultura, hay una relación directa entre integrarse al Sistema del Macho y sobrevivir" (Wilson Schaef, 1987: 35)

Por eso, no hay mayor pobreza que acostumbrarse a la miseria, como si nuestro destino fuera ser miserables. Pero hay que reconocer lo que muy certeramente también afirma A. Wilson Schaef: "Cuando uno está dentro de un ambiente contaminado, generalmente no se es consciente de ello (a no ser que se sea especialmente fuerte)" (Wilson Schaef, 1987: 34). La mujer transgresora se opone al "encierro", al "silencio" y a la "inercia" (recordad la Casa de Bernarda Alba) (Bodelón, 1995). Sin borrarse de la historia, la reescribe de su puño y letra. Hasta ahora la Historia, la Filosofía, la Teología y a Cultura en general sólo tenían nombre y características masculinas. Esto, gracias a vosotras, valientes, decididas y transgresoras, debe cambiar, ya está cambiando. Y es de agradecer.

\section{Proyecto de futuro. Un nUevo estilo de vida}

La propuesta es ser militantes de una vida creativa. Es romper las membranas que otros, pero también nosotros, casi sin darnos cuenta, hemos tejido para encerrarnos en un aislamiento suicida; es ser críticas y cultivar la capacidad de interrogarse continuamente, sin aceptar de forma pasiva los mitos y dogmas ancestrales, carentes de la más elemental veracidad; es lanzarse a la aventura de autoconstruirse, empleando la cabeza para pensar y no como percha o lugar del lacito. Es negaros a ser "mujeres útero". Además de útero, tenéis capacidad de pensar y de decidir; así, pues, que los hijos sean, si así lo decidís, fruto de la biología sabiamente gobernada y dirigida por la mente, fruto querido y deseado de vuestro proyecto, nunca hijos del azar, del atropello, de la sumisión y de la obediencia al "macho" de turno. La mujer libre no lucha sólo contra las presiones externas, sino contra su propia tentación de someterse y obedecer sin pensar, aceptando acríticamente que ha nacido para ser segundona y "descanso del guerrero". Cuidado con esas concepciones pseudoreligiosas que se mantienen en ciertos núcleos católicos que siguen queriendo mantener el modelo de mujer-útero (madre = hembra), equiparando equivocadamente a la mujer 
siempre abierta a la vida con la mujer siempre abierta al embarazo. Felizmente, son dos realidades muy diferentes.

La lucha contra esta degradación y opresión de la persona mujer no es, no debe ser sólo tarea vuestra. Nos compromete también a los varones, pues, como afirmamos al principio, "Mientras tú no seas plenamente TÚ y yo no sea plenamente YO, es inútil y vacío querer hablar del NOSOTROS". Luchad por estar en vuestro sitio, reconquistando posiciones de origen, pues, como dice el Talmud, “Dios no hizo a la mujer de los pies del varón para que fuera su esclava, ni la hizo de su cabeza para que mandara sobre él; sino que la sacó de su costado para que ambos, a la misma altura y mirándose a la cara, se amaran y respetaran mutuamente, haciéndose felices". Para eso hemos venido al mundo.

\section{REFERENCIAS BIBLIOGRÁFICAS}

Bansedon, N., Los derechos de la mujer, Mexico, FCE, 1988.

Bodelón, C., “La Casa de Bernarda Alba, símbolo de represión femenina”, en Dossier II Jornadas Estatales de Educación Sexual: Hacia una nueva relación entre los sexos, Inédito, Córdoba-León, 1995.

Lewontin-Rose-Kamin, No está en los genes. Racismo, genética e ideología, Barcelona, Ed. Crítica, 1987.

Mizrahi, L., Las mujeres y la culpa, Buenos Aires, Grupo editor Latino Americano, 1990.

----, La mujer transgresora, Barcelona, Emecé Editores, 1992.

----, Mujeres en plena revuelta, Buenos Aires, 2005.

Wilson Schaef, A., La mujer en un mundo masculino, Mexico, Ed. Pax, 1987. 